\title{
Numerical Analysis of Phenotypic Features and Protein Gel Electropherograms of Gluconobacter Asai 1935 emend. mut. char. Asai, Iizuka, and Komagata 1964
}

\author{
F. GOSSELÉ, J. SWINGS, K. KERSTERS, AND J. DE LEY* \\ Laboratorium voor Microbiologie en microbiële Genetica, Faculteit Wetenschappen, Rijksuniversiteit, $K$. L. \\ Ledeganckstraat 35, B-9000 Gent, Belgium
}

\begin{abstract}
Ninety-eight Gluconobacter strains of various origins were examined by numerical analysis of 177 phenotypic features and by gel electrophoresis of soluble proteins. Gluconobacter was phenotypically quite different from Acetobacter and Frateuria. An extensive phenotypic description and a minimal description of the genus Gluconobacter are given. The genus Gluconobacter contained two groups, $\mathrm{A}$ and $\mathrm{B}$, by both techniques. Phenons $\mathrm{A}$ and $\mathrm{B}$ could be differentiated only by the requirement for nicotinic acid and by their electrophoretic patterns. Protein electrophoresis showed clearly that Gluconobacter strains are genetically stable over several decades. The strains of all five subspecies of Gluconobacter oxydans cited in the Approved Lists of Bacterial Names (Skerman et al., Int. J. Syst. Bacteriol. 30:225-420, 1980) were distributed randomly over the phenotypic and electrophoretic clusters and subclusters, and the type strains of the subspecies all fell in phenon B. We conclude that the single species Gluconobacter oxydans should not be further divided into subspecies.
\end{abstract}

The acetic acid bacteria consist of the genera Acetobacter and Gluconobacter, which are both characterized by their capacity to oxidize ethanol to acetic acid. The polarly flagellated Gluconobacter does not oxidize lactate and acetate to $\mathrm{CO}_{2}$ and water, whereas the peritrichously flagellated Acetobacter does $(13,21,23,39)$.

Recently, Gillis and De Ley (24) demonstrated a very high similarity between the ribosomal ribonucleic acid (rRNA) cistrons from Acetobacter and Gluconobacter and proposed that both genera be placed in the family Acetobacteraceae. This is supported by extensive phenotypic similarities between both genera. Consequently, Gluconobacter and Acetobacter will be classified together in the family Acetobacteraceae in the ninth edition of Bergey's Manual of Determinative Bacteriology.

The generic name Gluconobacter was introduced by Asai (3). Unfortunately, his paper, written in Japanese, remained unknown in the West. The classification and nomenclature of this genus have been discussed extensively by De Ley and Frateur (20). In Bergey's Manual of Determinative Bacteriology (21), the type and sole species Gluconobacter oxydans was subdivided into four subspecies: G. oxydans, G. industrius, G. suboxydans, and G. melanogenes. These subspecies seemed justified at that time for practical and historic reasons. The system described in Bergey's Manual of Determinative Bacteriology (21) constituted a considerable simplification of a complicated older system of groups and species, and reduced the number of species to one. A fifth subspecies, Gluconobacter oxydans subsp. sphaericus, was added by Ameyama (1). The names of these five subspecies were preserved in the Approved Lists of Bacterial Names (48).

Loitianskaya et al. (40) applied numerical taxonomical methods to 136 phenotypic characters of 56 strains of acetic acid bacteria, including 15 gluconobacters. These authors found that the Acetobacter and Gluconobacter strains formed two well-separated groups, clustering at the simple matching coefficient $\left(\mathrm{S}_{\mathrm{SM}}\right)$ of $75 \%$. The results supported the existence of the species Gluconobacter oxydans within the genus Gluconobacter but cast doubt on the subspecies proposed in Bergey's Manual of Determinative Bacteriology (21).

Gillis and De Ley (24) found that authentic Gluconobacter and Acetobacter strains constituted well-defined and separate areas on the similarity map of the hybrids formed between their deoxyribonucleic acids (DNAs) and the 16S [ $\left.{ }^{14} \mathrm{C}\right] \mathrm{rRNA}$ fraction of Gluconobacter oxydans subsp. oxydans NCIB 9013. On the basis of similar studies, a new genus Frateuria was proposed for strains previously identified as "Acetobacter aurantius" (52).

In this study, 177 phenotypic features were compared and used to cluster 98 Gluconobacter, 17 Acetobacter, and 7 Frateuria aurantia strains 
by numerical analysis. The Acetobacter and Frateuria strains were included as controls only. We also compared and clustered Gluconobacter strains by polyacrylamide gel electrophoresis of their soluble proteins (32). It was our aim to give an extensive phenotypic description of the genus Gluconobacter, to determine the degree of its phenotypic and genetic homogeneity, to propose minimal standards for the genus, and to improve its classification. A similar study of a large collection of Acetobacter strains is in progress.

\section{MATERIALS AND METHODS}

Bacterial strains. The 98 Gluconobacter, 17 Aretobacter and 7 Frateuria strains used are listed in Table 1. They were grown and maintained either on GYC medium containing $5 \% \mathrm{D}$-glucose, $1 \%$ yeast extract (Oxoid Ltd.), $3 \% \mathrm{CaCO}_{3}$, and $2.5 \%$ agar or on MYP medium containing $2.5 \% \mathrm{D}$-mannitol, $0.5 \%$ yeast extract (Oxoid), $0.3 \%$ peptone (Oxoid), and $2.5 \%$ agar. The temperature for growth was always $28^{\circ} \mathrm{C}$. The standard medium (SM) consisted of $0.5 \%$ yeast extract and $5 \% \mathrm{D}$-glucose.

Nutritional, physiological, and biochemical tests. A total of 177 phenotypic features were tested. Most tests have been described previously (52). Resistance towards antibiotics was tested by the Kirby-Bauer method (9), using Oxoid antibiotic disks. The effect of different concentrations of metals and dyes on the growth of Gluconobacter was tested in a basal medium containing $0.05 \%$ yeast extract (Oxoid), $0.3 \%$ vitaminfree Casamino Acids (Difco Laboratories), 0.1\% Dglucose, $0.1 \%$ D-mannitol, $0.1 \%$ calcium-DL-lactate, and $2.5 \%$ agar (Oxoid no. 1). The medium of Asai et al. (5) was used to detect acid formation from different carbon sources. After 7 days of incubation at $28^{\circ} \mathrm{C}$, the $\mathrm{pH}$ was measured. The utilization of different carbon sources for growth was tested on a solid medium containing $0.5 \%$ yeast extract (Oxoid), $0.3 \%$ vitaminfree Casamino Acids (Difco), 2.5\% agar (Oxoid no. 1), and $0.3 \%$ of the carbon source. Growth factor requirements, the utilization of single L-amino acids as the sole sources of nitrogen, and the utilization of $\mathrm{L}$ alanine, L-aspartic acid, L-glutamic acid, or L-proline as the sole sources of both carbon and nitrogen were tested as described before $(26,27)$. The formation of acetyl methyl carbinol in a medium containing $0.1 \%$ yeast extract and 1\% calcium-DL-lactate was detected with Barritt's reagent (8) after 7 days of incubation.

Numerical analysis. Nearly all of the 177 phenotypic characters existed in one of two mutually exclusive states and were coded as 2 (positive) or 1 (negative). Multistate characters, such as pigmentation or colony morphology, were divided into several mutually exclusive states (49). For some strains, a few tests were missing (an average of 0.5 tests per strain), and such noncomparable results were coded as 0 (zero). The final $n \times t$ matrix comprised data for 122 strains and 188 unit characters. The $S_{\mathrm{SM}}$ and the Jaccard coefficient were calculated with the computer program of Bonham-Carter (11), adapted for the Siemens 7541 (BS 2000) computer of the Centraal Digitaal Rekencentrum, Rijksuniversiteit, Gent, Belgium. The strains were clustered according to the unweighted average pair-group method (49), using the Clustan 1C program (64).

Polyacrylamide gel electrophoresis of soluble proteins and numerical analysis of protein electropherograms. Cells were grown in Roux bottles on GYC medium for $40 \mathrm{~h}$ at $28^{\circ} \mathrm{C}$. Cell extracts were prepared and dialyzed as described previously (52). Polyacrylamide gel electrophoresis, densitometry and photography of the stained gels, normalization of the densitometric tracings, calculation of the Pearson product moment correlation coefficient $r$, and unweighted average linkage clustering were performed as described previously (31). At least $30 \%$ of the strains were grown in duplicate. Some strains, existing as duplicated cultures in different culture collections, were examined separately. For each protein extract at least three separate electrophoretic runs were performed.

\section{RESULTS}

Numerical analysis of morphological, biochemical, and physiological features. A dendrogram representing the results of the numerical analysis of the phenotypic features with the $S_{\mathrm{SM}}$ is given in Fig. 1. The seven Frateuria aurantia strains (52) grouped together above $76 \% \mathrm{~S}_{\mathrm{SM}}$ and separated clearly from the Acetobacter and Gluconobacter strains. Gluconobacter separated from Acetobacter at $68 \% \mathrm{~S}_{\mathrm{SM}}$. The $98 \mathrm{Glu}$ conobacter strains investigated were divided into two phenons, A (50 strains) and B (47 strains). One Gluconobacter oxydans subsp. suboxydans strain, i.e., IAM $1832 \mathrm{t}_{1}$, could not be assigned to either one of these phenons. No clearly separated subphenons could be distinguished within phenons $A$ and $B$. The position of each Gluconobacter strain within the dendrogram is indicated in Table 1 and Fig. 1.

The same phenons A and B were retrieved after analyzing the data with the Jaccard coefficient (figure not given). Some strains shifted their position somewhat, but there were no fundamental differences between Jaccard coefficient and $S_{S M}$ dendrograms.

For the different groups of phenotypic tests, the following reproducibilities were obtained: growth on carbon sources, $95 \%$; acid from carbon sources, 94\%; growth on single L-amino acids as the sole nitrogen source, $93 \%$; growth factor requirements, 97\%; growth in the presence of metals and dyes, 97\%. Independent retesting of the whole set of 177 phenotypic features on strain ATCC 15180 showed a reproducibility of $93 \%$.

All Gluconobacter strains displayed the following 20 features: occurrence of single cells; growth on $5 \%$ D-glucose- $0.5 \%$ yeast extract at $28^{\circ} \mathrm{C}$; final $\mathrm{pH}$ on $\mathrm{D}$-xylose below 4.5 ; final $\mathrm{pH}$ on D-ribose below 5.9; resistance per disk to 10 $\mu \mathrm{g}$ of gentamicin, $10 \mathrm{U}$ of bacitracin, $10 \mathrm{U}$ of penicillin $\mathrm{G}, 10 \mu \mathrm{g}$ of erythromycin, $2 \mu \mathrm{g}$ of lincomycin, $10 \mu \mathrm{g}$ of colistin sulfate, $10 \mu \mathrm{g}$ of 


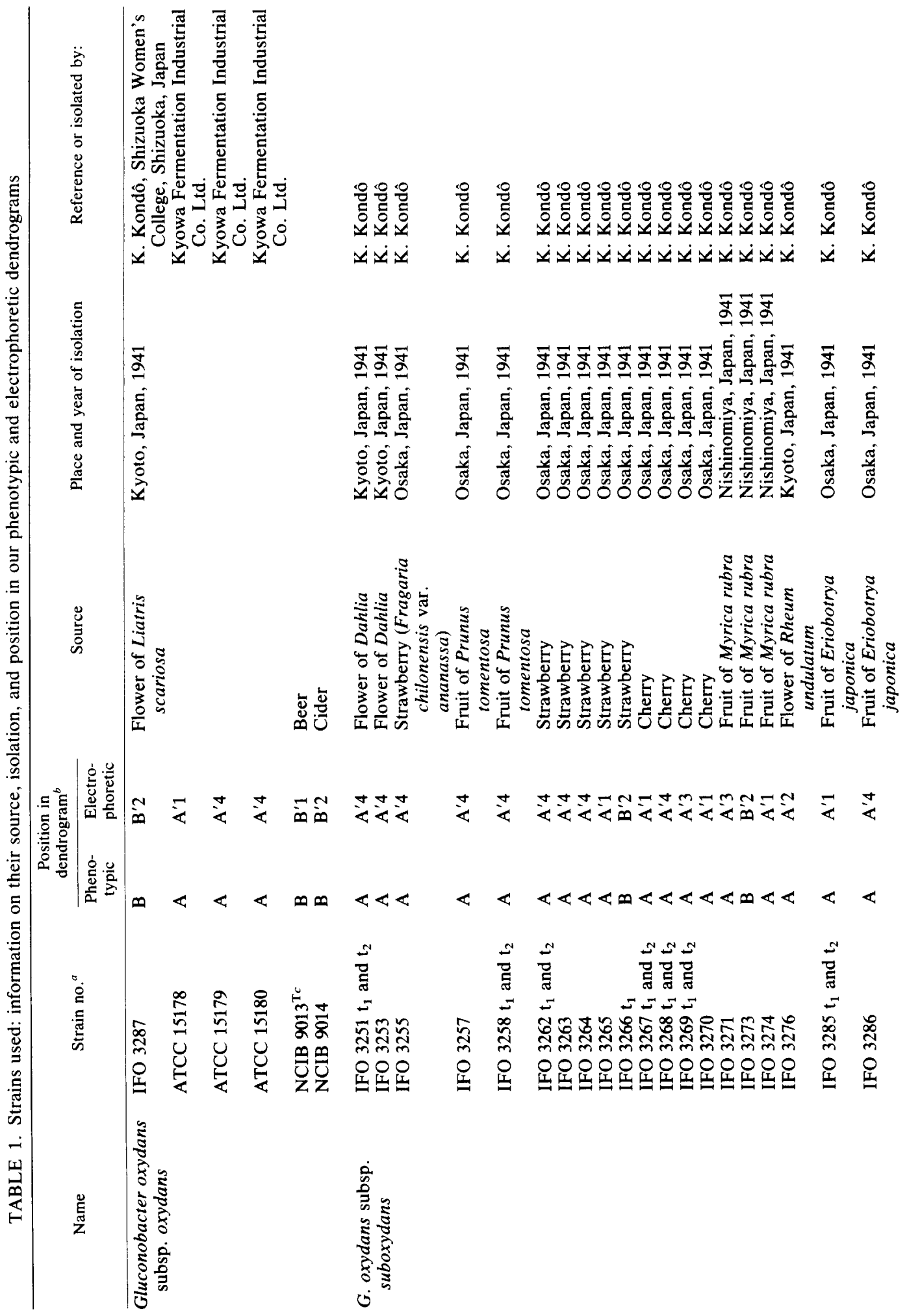




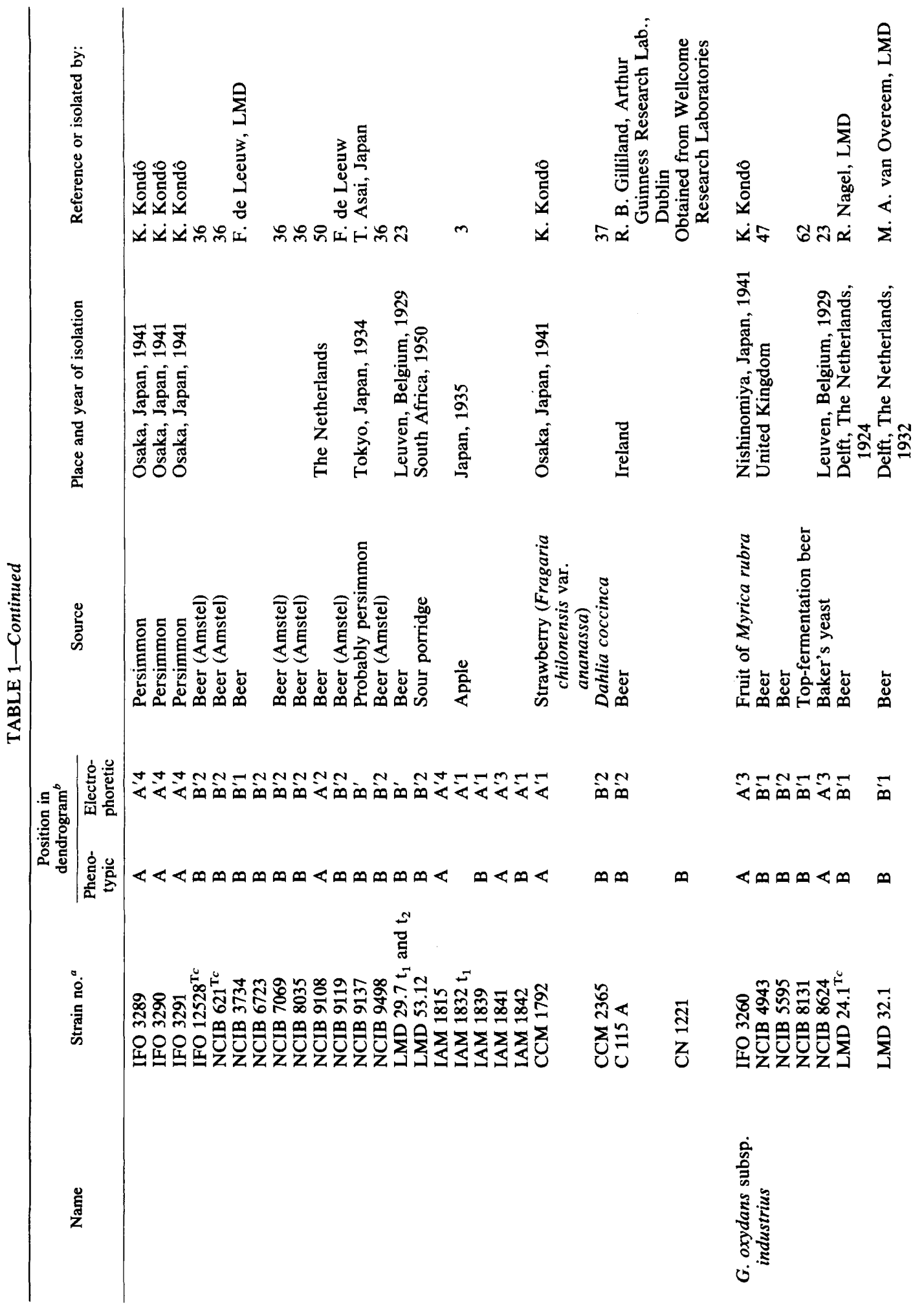



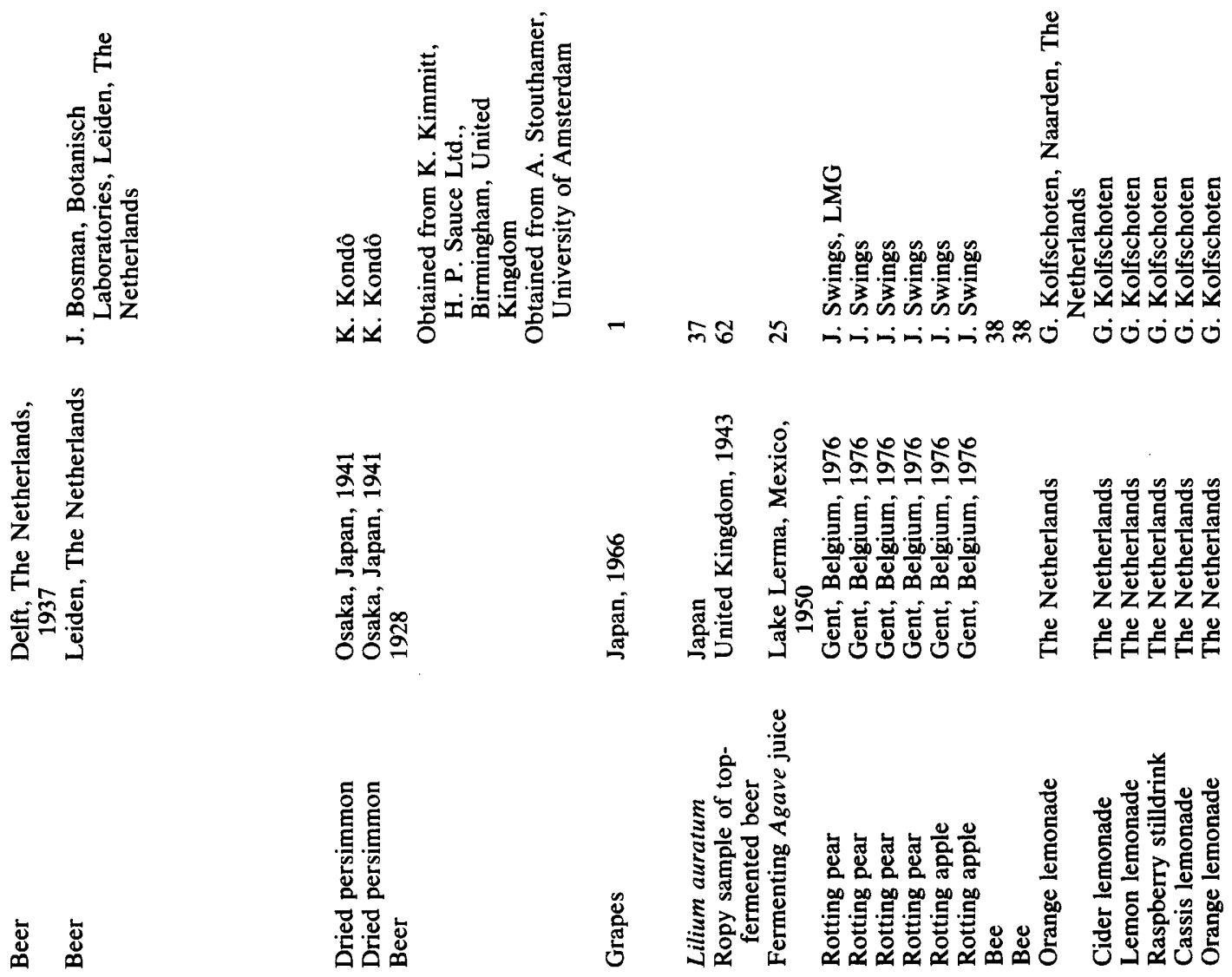

花

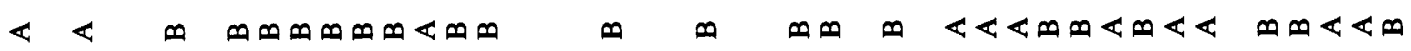

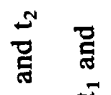

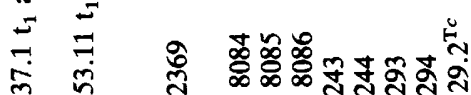

ค ค

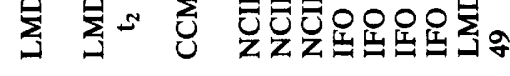
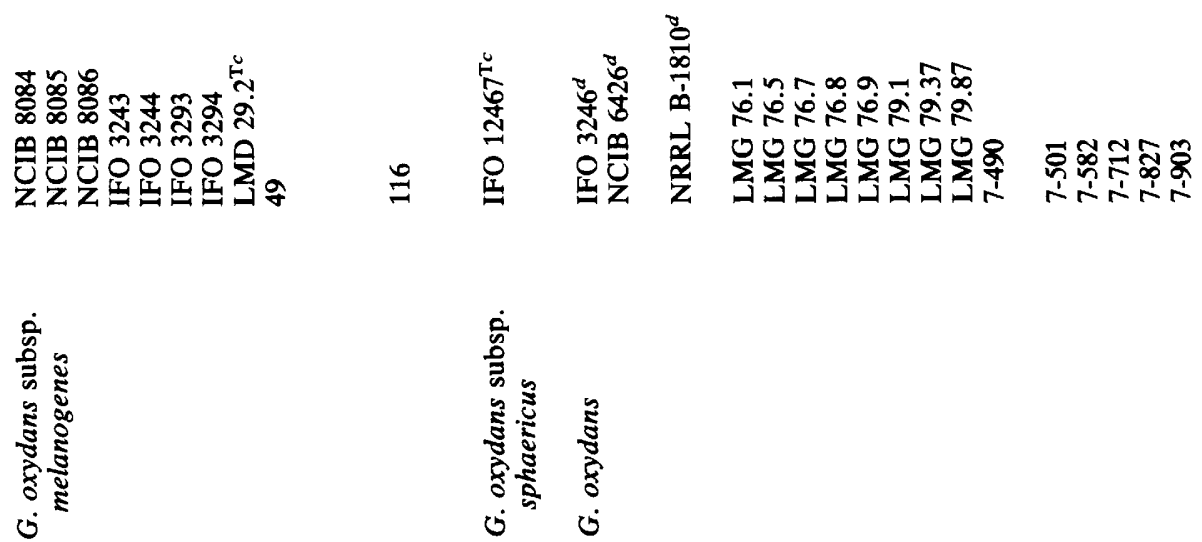


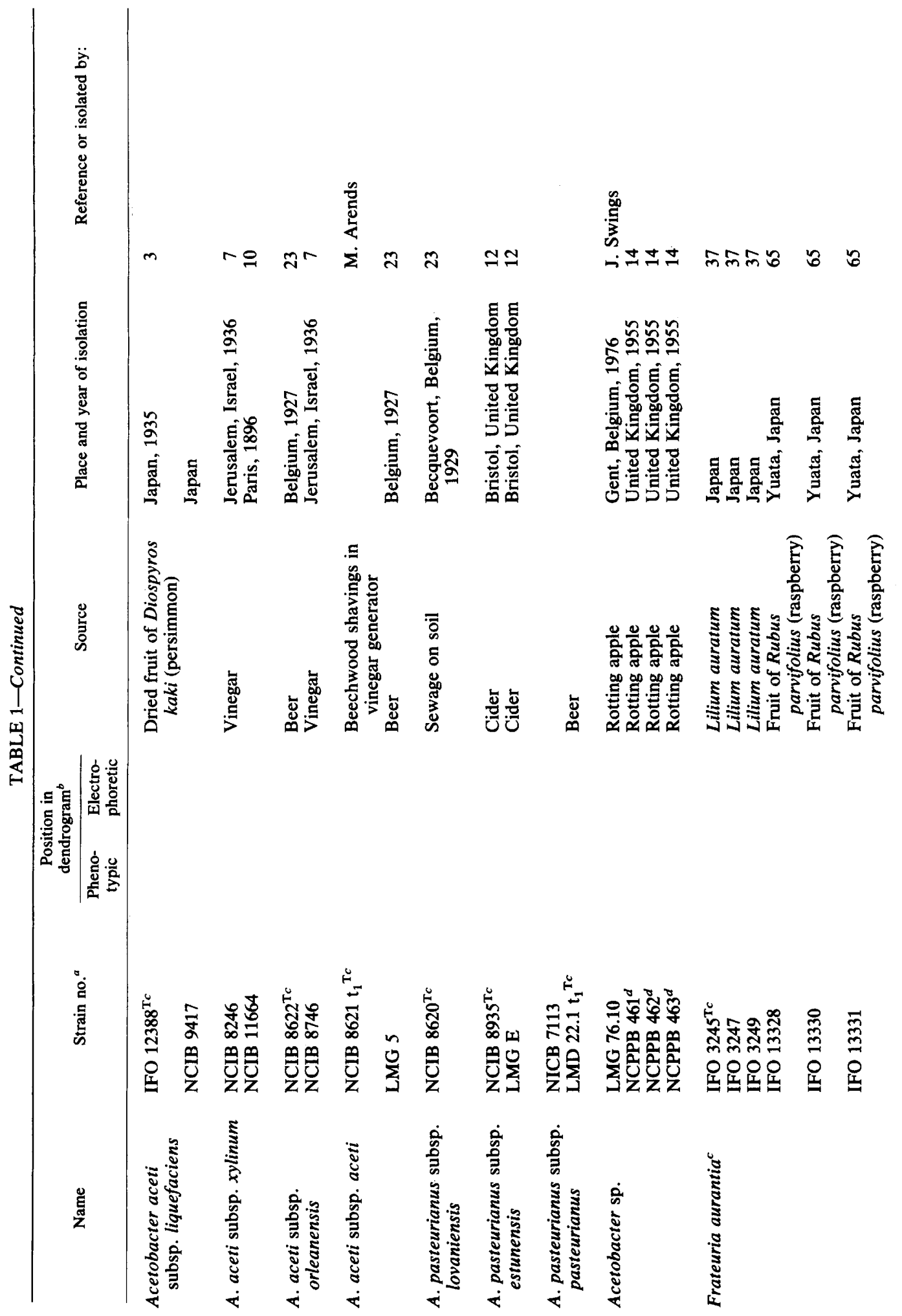




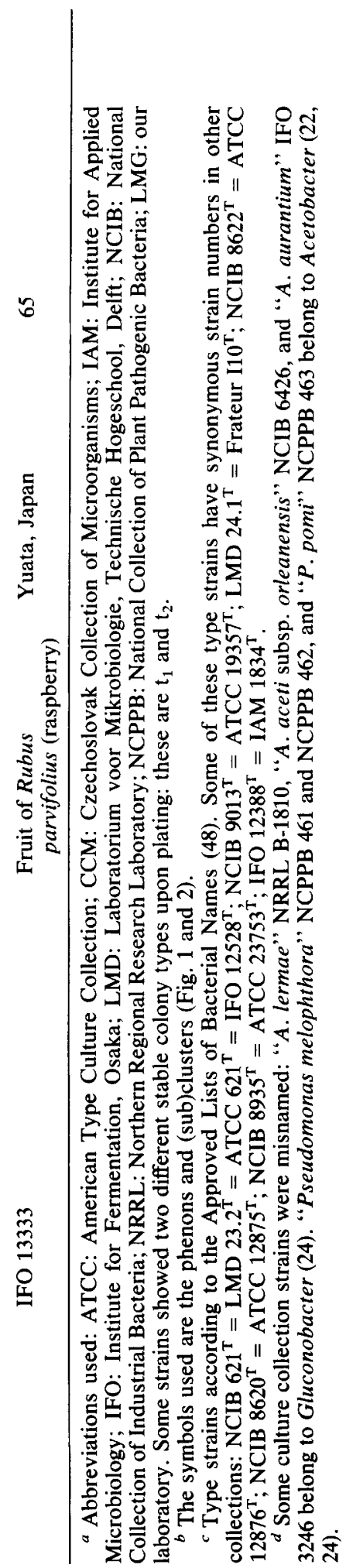

fucidin, $200 \mu \mathrm{g}$ of nitrofurantoin, $10 \mu \mathrm{g}$ of methicillin, $30 \mu \mathrm{g}$ of neomycin, $300 \mathrm{U}$ of polymyxin $\mathrm{B}$, $100 \mu \mathrm{g}$ of sulphafurazole; presence of catalase; formation of 2-ketogluconic acid from D-glucose; ketogenesis from glycerol; and growth factor requirements with D-mannitol as the carbon source.

All Gluconobacter strains lacked the following 39 features: growth on $0.5 \%$ yeast extract broth, $0.5 \%$ peptone broth, or nutrient broth; growth in anaerobic conditions; reaction in litmus milk; growth on Frateur's modified Hoyer medium with ethanol with or without growth factors; growth on $5 \%$ D-glucose- $0.5 \%$ yeast extract at $4^{\circ} \mathrm{C}$; growth on $5 \%$ D-glucose- $0.5 \%$ yeast extract and either $2 \% \mathrm{NaCl}$ or $10 \%$ ethanol; final $\mathrm{pH}$ on starch or lactose below 5.9; growth on ethanediol, galactitol, D-arabinose, Lrhamnose, D-mannose, L-lyxose, cellobiose, lactose, starch, sodium formate, sodium oxalate, sodium citrate, sodium malonate, sodium-potassium tartrate, calcium-DL-glycerate, or sodiumL-malate as the sole source of carbon; growth on L-alanine, L-aspartic acid, L-glutamic acid, or Lproline as the source of both carbon and nitrogen; presence of oxidase; reduction of nitrate; formation of indole; formation of $\mathrm{H}_{2} \mathrm{~S}$; gelatin liquefaction; oxidation of lactate or ethanol to $\mathrm{CO}_{2}$ and water.

All other features for which the Gluconobacter strains were studied gave differential results (Table 2).

Numerical comparison of gel electrophoretic protein patterns. Protein electropherograms were prepared for all of the Gluconobacter strains listed in Table 1, except strain CN 1221. More than 400 normalized electropherograms of 97 Gluconobacter strains were compared by numerical analysis. The reproducibility limits were above $r=\mathbf{0 . 9 5}$ for 82 strains and above $r=$ 0.93 for the remaining 15 strains. The most typical electropherogram of each strain (53) was used for the final clustering presented as a simplified dendrogram in Fig. 2. The protein electrophoretic heterogeneity of the Gluconobacter strains is obvious; at $r=0.75$ two electrophoretic clusters $A^{\prime}$ (53 strains) and $B^{\prime}$ (44 strains) could be delineated. With three exceptions, all strains belonging to the phenotypic phenon A belonged in the electrophoretic cluster $\mathrm{A}^{\prime}$ and all strains from phenon $\mathrm{B}$ fell in cluster $B^{\prime}$. Within clusters $A^{\prime}$ and $B^{\prime}$, respectively, four $\left(A^{\prime} 1\right.$ to $\left.A^{\prime} 4\right)$ and two $\left(B^{\prime} 1\right.$ and $\left.B^{\prime} 2\right)$ electrophoretic subclusters could be recognized at $r=0.90$. The electropherograms of the strains belonging to each subcluster were always very similar upon visual inspection. Phenotypic counterparts of these electrophoretic subclusters could not be detected in phenons $\mathrm{A}$ and $\mathrm{B}$. The position of each Gluconobacter strain within the electro- 
phoretic clusters $\mathrm{A}^{\prime}$ and $\mathrm{B}^{\prime}$ and their subclusters can be found in Table 1 . The following 12 strains of electrophoretic cluster $B^{\prime}$ could not be assigned to any of the subclusters: $G$. oxydans subsp. suboxydans NCIB 9137 and LMD $29.7 \mathrm{t}_{1}$ and $\mathrm{t}_{2}, G$. oxydans subsp. melanogenes strains 49, 116, and IFO 3293, G. oxydans subsp. sphaericus IFO $12467^{\mathrm{T}}, G$. oxydans NRRL B1810 , and $G$. oxydans strains 7-903 and LMG $76.8,76.9$, and 79.37. Normalized electropherograms of 30 representative Gluconobacter strains are shown in Fig. 3.

\section{DISCUSSION}

The named strains of the genus Gluconobacter will be considered first. It is obvious that they are quite different from Frateuria and from Acetobacter (Fig. 1).

Morphological, biochemical, and physiological features of Gluconobacter. Features which occur or are lacking in all Gluconobacter strains have been reported above.

The majority of the strains $(76 \%)$ were found to be nonmotile in our test conditions. The application of classical staining procedures (39, 42) revealed that all motile strains examined bore polar flagella. The difficulty of staining the flagella of acetic acid bacteria for light microscopy has been reported by several authors, e.g., Passmore (Ph.D. thesis, University of Bristol, Bristol, England, 1973). According to Loitianskaya et al. (41), the type of flagellation is not a

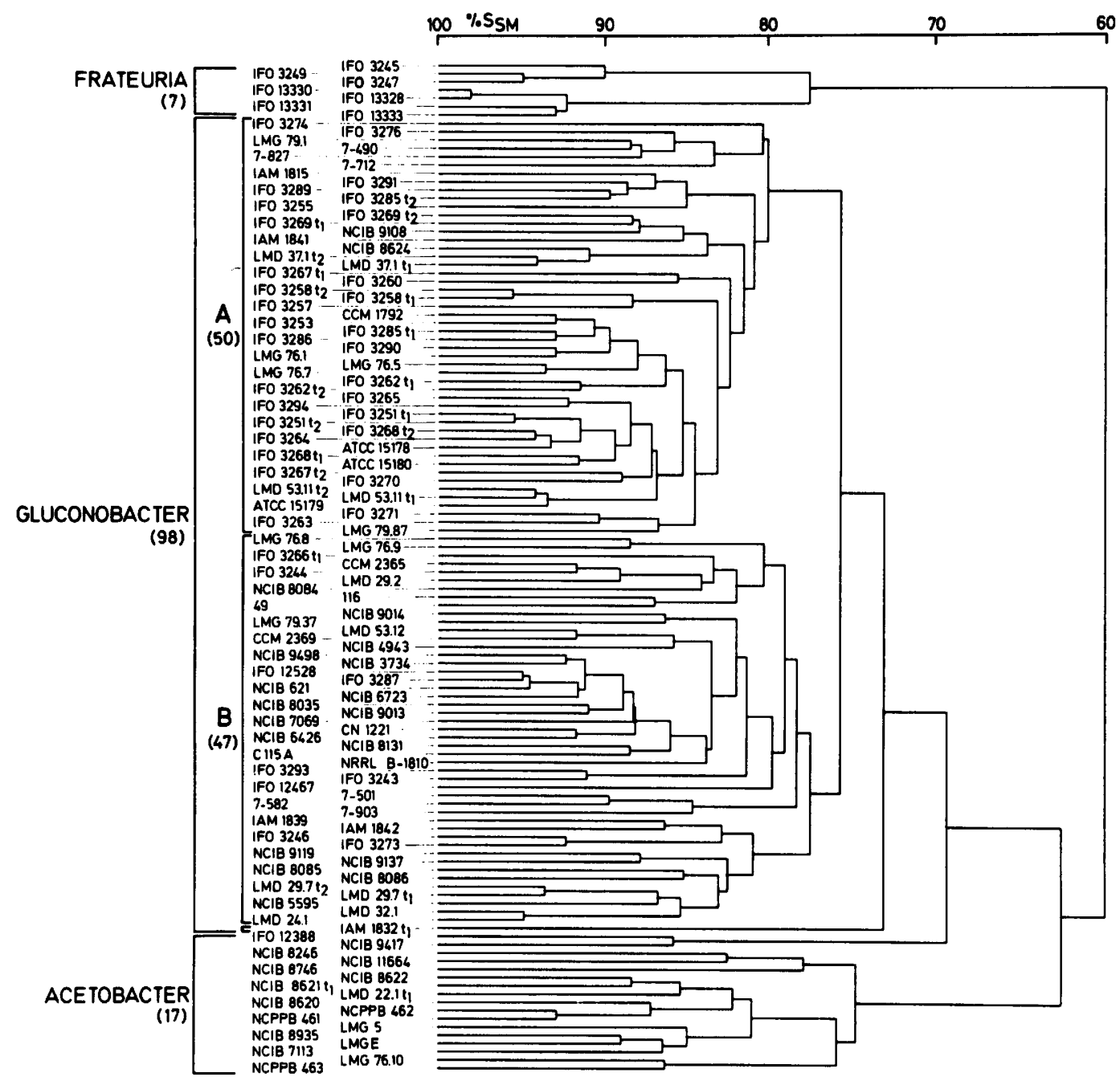

FIG. 1. Dendrogram obtained by numerical analysis of 177 phenotypic features of 98 Gluconobacter, 17 Acetobacter, and 7 Frateuria strains with the $S_{\mathrm{SM}}$ and the unweighted average pair-group method. The numbers of strains are given in parentheses. 
TABLE 2. Phenotypic features which are not uniformly positive or negative in 98 Gluconobacter strains

\begin{tabular}{|c|c|c|c|c|}
\hline \multirow[b]{2}{*}{ Feature } & \multicolumn{4}{|c|}{ Percentage of positive Gluconobacter strains } \\
\hline & $\begin{array}{c}\text { Phenon A } \\
\text { (50 strains) }\end{array}$ & $\begin{array}{l}\text { Phenon B } \\
\text { (47 strains) }\end{array}$ & $\begin{array}{l}\text { IAM } 1832 t_{1} \\
{\text { (1 strain })^{a}}^{a}\end{array}$ & $\begin{array}{c}\text { Total }(98 \\
\text { strains) }\end{array}$ \\
\hline \multicolumn{5}{|l|}{ Morphology after 10 days on GYC medium ${ }^{b}$} \\
\hline Moderate to abundant growth & 100 & 77 & 1 & 89 \\
\hline Luxuriant colony & 2 & 28 & 0 & 14 \\
\hline Pale colony colour & 84 & 55 & 1 & 70 \\
\hline Pink colony colour & 32 & 19 & $\mathbf{0}$ & 26 \\
\hline Soluble brown pigment & 0 & 21 & 0 & 10 \\
\hline Colony diameter $<3 \mathrm{~mm}$ & 54 & 85 & 1 & 69 \\
\hline Flat colony & 26 & 45 & 0 & 35 \\
\hline Regularly edged colony & 54 & 77 & 1 & 66 \\
\hline \multicolumn{5}{|l|}{ Cell morphology of 2- to 3-day-old cultures } \\
\hline Gram-negative cells & 90 & 89 & 1 & 90 \\
\hline Gram-variable cells & 10 & 11 & 0 & 10 \\
\hline Rods & 80 & 77 & 0 & 78 \\
\hline Ovoids & 34 & 49 & 1 & 42 \\
\hline Tapered cells & 30 & 4 & 0 & 17 \\
\hline Filaments & 64 & 45 & 0 & 54 \\
\hline Chains & 6 & 21 & 0 & 13 \\
\hline Cells in pairs & 94 & 96 & 1 & 95 \\
\hline Enlarged, irregular involution forms & 46 & 34 & 0 & 40 \\
\hline Curved cells & 48 & 38 & 0 & 43 \\
\hline Cell diameter $\geqslant 0.7 \mu \mathrm{m}$ & 22 & 26 & 0 & 23 \\
\hline Motile cells & 16 & 34 & 0 & 24 \\
\hline \multicolumn{5}{|l|}{ Acid production from: ${ }^{c}$} \\
\hline Ethanol & 86 & 89 & 1 & 88 \\
\hline n-Propanol & 94 & 96 & 0 & 94 \\
\hline n-Butanol & 83 & 96 & NT & 88 \\
\hline n-Amylalcohol & 57 & 56 & 0 & 56 \\
\hline Glycerol & 96 & 79 & 0 & 87 \\
\hline meso-Erythritol & 98 & 94 & 1 & 96 \\
\hline D-Mannitol & 92 & 85 & 0 & 87 \\
\hline D-Glucitol & 68 & 70 & 0 & 68 \\
\hline meso-Inositol & 28 & 4 & 1 & 17 \\
\hline D-Arabinose & 98 & 100 & 1 & 99 \\
\hline L-Rhamnose & 4 & 2 & 0 & 3 \\
\hline D-Galactose & 84 & 94 & 1 & 89 \\
\hline D-Glucose & 100 & 98 & 1 & 99 \\
\hline D-Fructose & 92 & 94 & 1 & 93 \\
\hline D-Mannose & 94 & 96 & 1 & 95 \\
\hline L-Sorbose & 40 & 54 & 0 & 46 \\
\hline Cellobiose & 6 & 2 & 0 & 4 \\
\hline Maltose & 78 & 98 & 1 & 88 \\
\hline Sucrose & 76 & 53 & 0 & 64 \\
\hline Raffinose & 6 & 4 & 0 & 5 \\
\hline Dextrin & 4 & 0 & 0 & 2 \\
\hline \multicolumn{5}{|l|}{ Growth on: } \\
\hline \multicolumn{5}{|l|}{ Frateur's Hoyer medium } \\
\hline With glucose and growth factors & 88 & 62 & 0 & 74 \\
\hline With D-mannitol and growth factors & 100 & 89 & 1 & 95 \\
\hline \multicolumn{5}{|l|}{$\mathrm{SM}^{d}$ containing } \\
\hline $0.5 \% \mathrm{NaCl}$ & 70 & 66 & 0 & 67 \\
\hline $1 \% \mathrm{NaCl}$ & 40 & 26 & 0 & 33 \\
\hline $1 \%$ ethanol & 88 & 94 & 0 & 90 \\
\hline $2 \%$ ethanol & 88 & 89 & 0 & 88 \\
\hline $5 \%$ ethanol & 20 & 64 & 0 & 41 \\
\hline \multicolumn{4}{|l|}{$\mathrm{SM}^{d}$ at } & 41 \\
\hline
\end{tabular}


TABLE 2-Continued

\begin{tabular}{|c|c|c|c|c|}
\hline \multirow[b]{2}{*}{ Feature } & \multicolumn{4}{|c|}{ Percentage of positive Gluconobacter strains } \\
\hline & $\begin{array}{l}\text { Phenon A } \\
\text { (50 strains) }\end{array}$ & $\begin{array}{l}\text { Phenon B } \\
\text { (47 strains) }\end{array}$ & $\begin{array}{l}\text { IAM } 1832 \mathrm{t}_{1} \\
(1 \text { strain })^{a}\end{array}$ & $\begin{array}{c}\text { Total (98 } \\
\text { strains) }\end{array}$ \\
\hline $37^{\circ} \mathrm{C}$ & 2 & 0 & 0 & 1 \\
\hline pH 3.6 & 86 & 89 & 1 & 88 \\
\hline \multicolumn{5}{|l|}{$0.5 \%$ yeast extract containing } \\
\hline $20 \%$ D-glucose & 62 & 38 & 0 & 50 \\
\hline $25 \%$ D-glucose & 36 & 17 & 0 & 27 \\
\hline $30 \%$ D-glucose & 18 & 2 & 0 & 10 \\
\hline \multicolumn{5}{|l|}{ Carbon sources for growth } \\
\hline Methanol & 2 & 0 & 0 & 1 \\
\hline Ethanol & 10 & 11 & 1 & 11 \\
\hline$n$-Propanol & 10 & 9 & 0 & 9 \\
\hline Glycerol & 98 & 83 & 1 & 91 \\
\hline meso-Erythritol & 58 & 74 & 0 & 65 \\
\hline meso-Ribitol & 82 & 11 & 0 & 47 \\
\hline meso-Xylitol & 96 & 15 & 0 & 47 \\
\hline L-Arabitol & 78 & 4 & 0 & 42 \\
\hline meso-Inositol & 40 & 9 & 0 & 24 \\
\hline D-Mannitol & 98 & 89 & 1 & 94 \\
\hline D-Glucitol & 98 & 89 & 1 & 94 \\
\hline L-Arabinose & 2 & 2 & 0 & 2 \\
\hline D-Ribose & 20 & 2 & 0 & 11 \\
\hline D-Xylose & 2 & 2 & 0 & 2 \\
\hline D-Fructose & 92 & 83 & 0 & 87 \\
\hline D-Galactose & 0 & 2 & 0 & 1 \\
\hline D-Glucose & 96 & 62 & 0 & 79 \\
\hline Calcium-D-gluconate & 52 & 36 & 1 & 45 \\
\hline L-Sorbose & 56 & 36 & 0 & 46 \\
\hline D-Lyxose & 2 & 0 & 0 & 1 \\
\hline D-Fucose & 18 & 13 & 0 & $\hat{15}$ \\
\hline Maltose & 18 & 30 & 0 & 23 \\
\hline Sucrose & 34 & 13 & 0 & 23 \\
\hline Raffinose & 8 & 0 & 0 & 4 \\
\hline Dextrin & 0 & 7 & 0 & 3 \\
\hline Sodium acetate & 0 & 0 & 1 & 1 \\
\hline Sodium-DL-lactate & 6 & 7 & 0 & 6 \\
\hline \multicolumn{5}{|l|}{ Biochemical reactions } \\
\hline Production of 5-ketogluconic acid from D-glucose & 96 & 94 & 1 & 95 \\
\hline $\begin{array}{l}\text { Production of 2,5-diketogluconic acid from D- } \\
\text { glucose }\end{array}$ & 0 & 35 & 0 & 16 \\
\hline \multicolumn{5}{|l|}{ Ferric chloride reaction on } \\
\hline D-Glucose & 0 & 32 & 0 & 16 \\
\hline D-Fructose & 89 & 87 & 1 & 89 \\
\hline D-Galactose & 2 & 0 & 0 & 1 \\
\hline \multicolumn{5}{|l|}{ Ketogenesis from: } \\
\hline D-Mannitol & 98 & 98 & 1 & 98 \\
\hline D-Glucitol & 100 & 98 & 1 & 99 \\
\hline $\begin{array}{l}\text { Production of acetylmethylcarbinol from calcium- } \\
\text { DL-lactate }\end{array}$ & 78 & 83 & 1 & 81 \\
\hline \multicolumn{5}{|l|}{ Single L-amino acid as sole source of nitrogen } \\
\hline L-Alanine & 92 & 45 & 1 & 69 \\
\hline L-Arginine & 94 & 32 & 1 & 64 \\
\hline L-Asparagine & 100 & 89 & 1 & 95 \\
\hline L-Aspartic acid & 98 & 68 & 1 & 84 \\
\hline L-Cysteine & 66 & 15 & 1 & 42 \\
\hline
\end{tabular}


TABLE 2-Continued

\begin{tabular}{|c|c|c|c|c|}
\hline \multirow[b]{2}{*}{ Feature } & \multicolumn{4}{|c|}{ Percentage of positive Gluconobacter strains } \\
\hline & $\begin{array}{l}\text { Phenon A } \\
\text { (50 strains) }\end{array}$ & $\begin{array}{l}\text { Phenon B } \\
\text { (47 strains) }\end{array}$ & $\begin{array}{l}\text { IAM } 1832 \mathrm{t}_{1} \\
(1 \text { strain })^{a}\end{array}$ & $\begin{array}{c}\text { Total (98 } \\
\text { strains) }\end{array}$ \\
\hline L-Glutamine & 98 & 89 & 1 & 94 \\
\hline L-Glutamic acid & 98 & 77 & 1 & 88 \\
\hline L-Glycine & 40 & 23 & 0 & 32 \\
\hline L-Histidine & 46 & 60 & $\mathbf{0}$ & 52 \\
\hline L-Isoleucine & 92 & 38 & 1 & 66 \\
\hline L-Leucine & 80 & 2 & 0 & 42 \\
\hline L-Lysine & 86 & 32 & 1 & 60 \\
\hline L-Methionine & 78 & 34 & 1 & 56 \\
\hline L-Phenylalanine & 88 & 26 & 1 & 58 \\
\hline L-Proline & 96 & 62 & 1 & 80 \\
\hline L-Serine & 48 & 36 & 1 & 43 \\
\hline L-Threonine & 56 & 28 & 0 & 42 \\
\hline L-Tryptophan & 78 & 36 & 1 & 58 \\
\hline L-Tyrosine & 72 & 23 & 0 & 48 \\
\hline L-Valine & 38 & 0 & 0 & 19 \\
\hline \multicolumn{5}{|c|}{$\begin{array}{l}\text { Growth factor requirements in the presence of } D- \\
\text { mannitol as carbon source }\end{array}$} \\
\hline p-Aminobenzoic acid & 2 & 19 & 1 & 11 \\
\hline Thiamine & 0 & 26 & 1 & 13 \\
\hline Nicotinic acid & 0 & 98 & 1 & 48 \\
\hline Pantothenic acid & 100 & 89 & 1 & 95 \\
\hline Other growth factors & 0 & 6 & 1 & 4 \\
\hline \multicolumn{5}{|l|}{ Resistance to antibiotics } \\
\hline Kanamycin $(30 \mu \mathrm{g})$ & 48 & 19 & 0 & 34 \\
\hline Streptomycin $(10 \mu \mathrm{g})$ & 62 & 23 & 0 & 43 \\
\hline Tetracycline $(30 \mu \mathrm{g})$ & 6 & 7 & 0 & 6 \\
\hline Novobiocin $(30 \mu \mathrm{g})$ & 4 & 7 & 1 & 6 \\
\hline Ampicillin $(10 \mu \mathrm{g})$ & 86 & 77 & 1 & 82 \\
\hline Nalidixic acid $(30 \mu \mathrm{g})$ & 94 & 87 & 1 & 91 \\
\hline Chloramphenicol $(30 \mu \mathrm{g})$ & 98 & 96 & 0 & 96 \\
\hline Cephaloridin $(25 \mu \mathrm{g})$ & 84 & 96 & 1 & 90 \\
\hline \multicolumn{5}{|c|}{ Growth in the presence of metals and dyes } \\
\hline $0.001 \%$ Malachite green & 98 & 49 & 0 & 74 \\
\hline $0.0001 \%$ Crystal violet & 82 & 51 & 1 & 67 \\
\hline $0.001 \%$ Brilliant green & 94 & 46 & 0 & 70 \\
\hline $0.01 \% \mathrm{Cd}\left(\mathrm{CH}_{3} \cdot \mathrm{COO}\right)_{2} \cdot 2 \mathrm{H}_{2} \mathrm{O}$ & 28 & 32 & 0 & 30 \\
\hline $0.01 \% \mathrm{CoSO}_{4} \cdot 7 \mathrm{H}_{2} \mathrm{O}$ & 54 & 13 & 1 & 35 \\
\hline $0.001 \% \mathrm{HgCl}_{2}$ & 42 & 26 & 0 & 34 \\
\hline $0.001 \%$ Tl-OOC $\cdot \mathrm{CH}_{3}$ & 92 & 79 & 0 & 85 \\
\hline
\end{tabular}

${ }^{a}$ Since only one strain was available, the results are represented by 0 (feature absent) or 1 (feature present). NT, not tested.

${ }^{b} \mathrm{GYC}$ medium. See text.

c A final pH below 5.9 was considered as positive for acid formation for all carbon sources, except for Dglucose, D-xylose, and D-galactose for which $\mathrm{pH} 4.5$ was taken.

${ }^{d}$ SM medium. See text.

reliable character among the acetic acid bacteria and is of little use for the differentiation of Acetobacter and Gluconobacter.

Gram variability and the formation of enlarged, irregular cells (" "hypertrophische Zellformen" [30]; "involution forms") are not restricted to older cultures as previously thought. These features occurred in $10 \%$ and $40 \%$, respectively, of the Gluconobacter strains. Passmore (Ph.D. thesis, University of Bristol, Bristol, England, 1973) has suggested that involution forms might be a stage in a life cycle.

The presence of a water-insoluble pink pigment has been used as a diagnostic feature in previous classifications $(3,55,59-61)$. Frateur (23) noted that the formation of a pink pigment is 
not a reliable taxonomic feature. It can also be confused with the presence of cytochromes. Consequently, De Ley and Frateur (21) did not use it as a diagnostic characteristic. Our results (Table 2) show that pink pigments were formed by strains from both phenons $A$ and $B$. In all strains tested, the formation of a water-soluble, coffee-brown pigment correlated with the production of 2,5-diketogluconic acid and $\gamma$-pyrones from $\mathrm{D}$-glucose.

Nearly all strains possessed ketogenic activity towards the sugars and polyalcohols tested. The formation of 2-keto- and 5-ketogluconic acid from D-glucose, found in 100 and $95 \%$, respectively, of the strains, is a reliable generic feature of Gluconobacter.

More than $85 \%$ of the Gluconobacter strains formed acid from ethanol, 1-propanol, 1-butanol, glycerol, meso-erythritol, D-mannitol, Dxylose, D-arabinose, D-ribose, D-glucose, D-galactose, D-fructose, D-mannose, and maltose, Acid formation from L-rhamnose, cellobiose, lactose, raffinose, dextrin, and starch was only rarely observed, as less than $5 \%$ of the strains were positive. This confirms the data of Asai (3), Asai and Shoda (6), De Ley (18), Asai et al. (5),

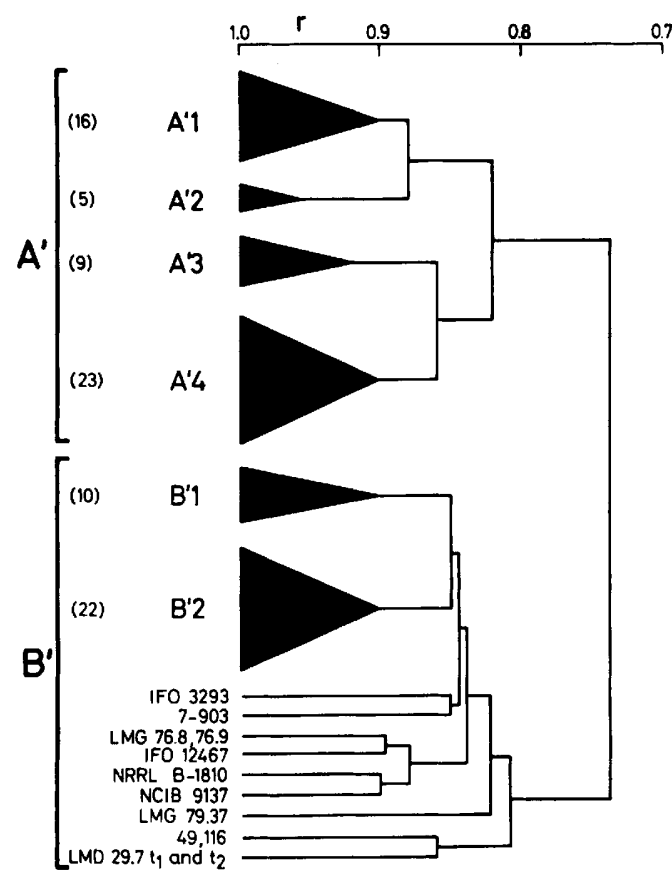

FIG. 2. Simplified dendrogram of correlation coefficients $r$, grouped by the unweighted average pairgroup method, showing the relationships between protein electropherograms of 97 Gluconobacter strains. Electrophoretic (sub)clusters are labeled as in the text and in Fig. 3. The number of strains is indicated in parentheses to the left of the subcluster label. Strain numbers are given for single strains. and De Ley and Frateur $(20,21)$.

The formation of acetic acid from ethanol is the most striking common feature of acetic acid bacteria. In liquid media, however, only $88 \%$ of the Gluconobacter strains acidified ethanol. When Carr's procedure (13) on agar medium was used, only two of the 98 Gluconobacter strains, i.e., NCIB 9498 and IAM $1832 \mathrm{t}_{1}$, failed to form acetic acid from ethanol. However, both strains formed some acid from ethanol in the liquid medium of Asai et al. (5). The former strain is a variant of strain NCIB 8036, which is itself a descendant of the type strain NCIB $621^{\mathrm{T}}$ of $G$. oxydans subsp. suboxydans. Fig. 1 shows that NCIB $621^{\mathrm{T}}$ and NCIB 9498 cluster together at $91 \% \mathrm{~S}_{\mathrm{SM}}$ in the middle of phenon B. Gillis and De Ley (24) showed by DNA:rRNA hybridizations that strain NCIB 9498 belongs to the genus Gluconobacter. Its protein pattern is almost indistinguishable from the patterns of strain NCIB 621 ${ }^{\mathrm{T}}$ and NCIB 7069 (Fig. 3). We conclude that strain NCIB 9498 is a normal Gluconobacter, in spite of its poor ethanol oxidation. Strain IAM 1832 will be discussed below.

It appears that the ability to oxidize ethanol extensively to acetic acid is not necessarily an essential characteristic of Gluconobacter. For ethanol-oxidizing strains, a rapid, simple and accurate differentiation of Gluconobacter from Acetobacter is possible, as the former does not oxidize ethanol via acetate to $\mathrm{CO}_{2}$ and water whereas the latter does.

Acid production from a carbohydrate does not imply that growth is sustained by it, e.g., whereas all strains acidified $\mathrm{D}$-xylose $(\mathrm{pH} \leqslant 4.50)$, only $2 \%$ were able to grow on it. As stated by Henneberg (30), "wenn auch Säuerung zu konstatieren war, konnte in verschiedenen Fälle keine Hautbildung wahrgenommen werden.", The best carbon sources for growth of Gluconobacter were, in descending order: D-mannitol, D-glucitol, glycerol, D-fructose, and D-glucose.

As Gluconobacter strains have no complete tricarboxylic acid cycle enzyme sequence (15, $28,29,34,35,63$ ), it is not surprising that no growth was obtained on the tricarboxylic acid cycle intermediates citrate and malate.

The majority of Gluconobacter strains were able to utilize L-asparagine, L-aspartic acid, Lglutamine, L-glutamic acid, and L-proline as sole sources of nitrogen for growth. It is known that these amino acids play a key role in the nutrition of Gluconobacter. The majority of Gluconobacter strains $(81 \%)$ did not grow with L-valine as the sole source of nitrogen. This phenomenon might be due to the inhibitory effect of this amino acid $(17,33$; R. J. Shamberger, M.S. Thesis, Oregon State University, Corvallis, 1960). A discussion of the nitrogen requirements of Gluconobacter, Acetobacter, and Frateuria 
has been given elsewhere (27).

The acid-tolerant character of Gluconobacter was stressed by Asai (3). We found that $88 \%$ of the strains grew at $\mathrm{pH}$ 3.6.

It has been reported that the members of the genus Gluconobacter tolerate 1 to $7 \%$ ethanol (3, 54; S. M. Passmore, Ph.D. thesis). These observations correspond well with our findings. In the presence of 1,2 , and $5 \%$ ethanol, 90,88 , and $41 \%$, respectively, of the strains grew. Phenon B contained the most ethanol-resistant strains. This is not surprising as $\mathbf{2 0}$ strains from phenon $B$ were isolated from alcohol-containing environments, e.g., beer, cider, and fermenting Agave juice.

Another striking feature of the genus Gluconobacter is its glucose tolerance, as $27 \%$ of the strains grew in the presence of $25 \%$ glucose. This confirms earlier observations $(23,56)$.

Heterogeneity within the genus Gluconobacter. With the exception of strains IAM 1842, IAM 1839 , and IAM $1832 t_{1}$, every strain which clustered in either phenon A or B in the numerical taxonomic study also fell into the electrophoretic cluster $\mathbf{A}^{\prime}$ or $\mathbf{B}^{\prime}$, respectively (see Table 1 ). However, strains IAM 1842 and IAM 1839 belonged to the electrophoretic subcluster $A^{\prime} 1$, but were members of phenon $B$.

This subdivision of Gluconobacter into two phenons $A$ and $B$ occurs on the basis of two different sets of criteria. They can be differentiated by two features only: differences in the electrophoretic protein profiles and in the requirement for nicotinic acid for growth. Nicotinic acid is required by $98 \%$ of the strains from phenon $B$ and none of the strains from phenon A. This constitutes the sole phenotypic feature differentiating phenons $A$ and $B$. A discussion of the growth factor requirements of Gluconobacter can be found elsewhere (26). Although the differentiation is never complete, there are other phenotypic features which tend to separate the phenons. These are the following.

(i) On the whole, strains of phenon A were better equipped to use the pentitols meso-ribitol, meso-xylitol, and L-arabitol as carbon sources.

(ii) The utilization of single L-amino acids as the sole source of nitrogen was more widespread among strains from phenon $A$ than from phenon B. This is particularly true for L-leucine, which supported growth of $80 \%$ of the strains from phenon A, but only $2 \%$ from phenon B.

(iii) A water-soluble, coffee-brown pigment was formed by $21 \%$ of the strains from phenon

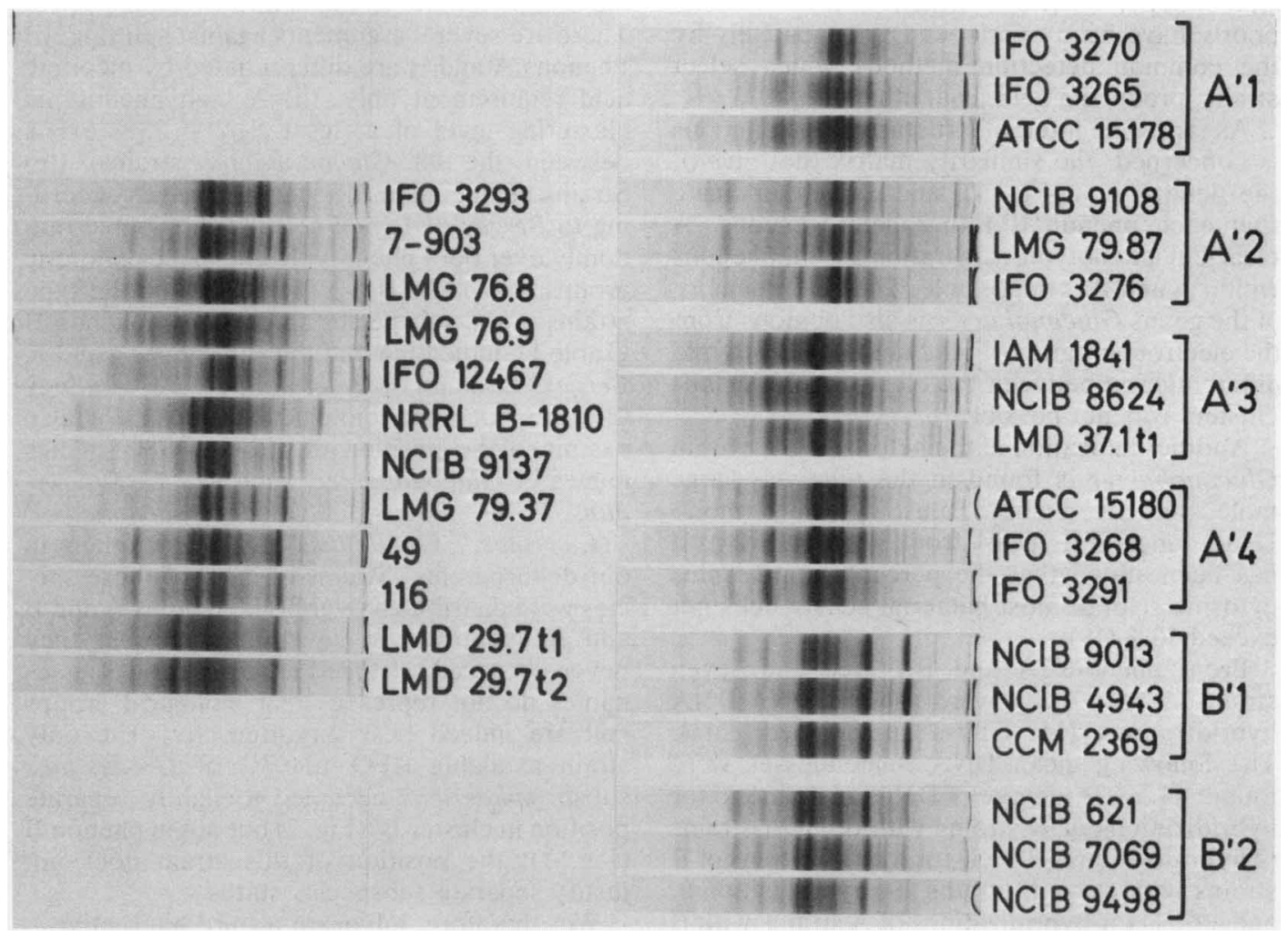

FIG. 3. Normalized protein electropherograms of 30 representative Gluconobacter oxydans strains. A'1, $\mathbf{A}^{\prime} 2$, etc. refer to (sub)clusters of Fig. 2 and Table 1. Strain numbers refer to strains from Table 1. 
B, but by no strain from phenon A. In Bergey's Manual of Determinative Bacteriology (21), this feature was reported for strains of the $G$. oxydans subspecies industrius and melanogenes.

(iv) Glucose tolerance was more obvious in phenon $A$ than in phenon $B$. It should be added that phenon A contained 41 strains isolated from sugar-containing sources such as fruits, flowers, and soft drinks. The nature of the original environment seems to be reflected in the sugar and ethanol tolerance of the isolates.

(v) Resistance towards antibiotics, metals, and dyes was more widespread in phenon A.

Strain $G$. oxydans subsp. suboxydans IAM $1832 t_{1}$ is a separate case; it is phenotypically quite different from phenons $\mathrm{A}$ or $\mathrm{B}$ but belongs electrophoretically to the subcluster $A^{\prime} 1$. Asai (4) discussed and identified this strain as a Gluconobacter. Our results confirm this, as it shares a large number of features with the other Gluconobacter strains. The single strain IAM $1832 t_{1}$ can be partially differentiated by a number of features from both phenon $A$ and phenon B (Table 2). Strain IAM $1832 t_{1}$ is outstanding in that it produces little or no (according to the conditions) acetic acid from ethanol. One explanation for the lack of other strains resembling strain IAM 1832 might be that a number of Gluconobacter strains which oxidize ethanol poorly have been overlooked systematically by the common detection methods which select strains producing acid from ethanol.

As far as the internal structure of the phenons is concerned, the similarity matrix (not given), the dendrogram (Fig. 1), and Table 2 indicate that each phenon is rather heterogeneous. A clear-cut phenotypic separation of subphenons within $A$ and $B$ is impossible. The heterogeneity of the genus Gluconobacter is also obvious from the electropherogram (Fig. 2 and 3). Phenotypic differentiation between the electrophoretic subclusters was not possible.

Another indication of the heterogeneity within Gluconobacter is found in the relatively large mole percent guanine plus cytosine (mol\% $\mathrm{G}+\mathrm{C}$ ) range in its DNA from 56 to $64 \%$ (24). It has been stated that the percent guanine plus cytosine span of most bacterial genera does not exceed $10 \%$ (19).

From phenons $\mathrm{A}$ and $\mathrm{B}$, three and seven strains, respectively, were used in DNA:DNA hybridizations (M. Gillis, unpublished data). The following mean DNA relatednesses were found: $44.5 \% \mathrm{D}$ (degree of DNA relatedness) for hybridizations of A strains with other A strains ( 2 hybridizations), $81 \% \mathrm{D}$ for hybridizations of $\mathrm{B}$ strains with other B strains (14 hybridizations), and $30 \% \mathrm{D}$ for hybridizations of $\mathrm{A}$ strains with $\mathrm{B}$ strains (13 hybridizations). Within these three series of hybridizations, the lowest DNA rela- tednesses obtained were, respectively, $27 \% \mathrm{D}$, $40 \% \mathrm{D}$, and $16 \% \mathrm{D}$, confirming the genetic heterogeneity within Gluconobacter oxydans.

Taxonomy of Gluconobacter. Gluconobacter constitutes a well-defined genus that can be distinguished easily from Acetobacter by its inability to oxidize acetate and lactate to $\mathrm{CO}_{2}$ and water. We propose the following minimal standards for the genus Gluconobacter. Cells ellipsoidal to rod shaped; endospores not formed; gram negative or variable. The majority of the strains nonmotile; if motile, the flagellation is polar. Obligately aerobic, possessing a strictly respiratory type of metabolism. Never fermentative. Strong catalase activity. No oxidase. Oxidizes ethanol to acetic acid; rarely very weakly. Does not oxidize acetate or lactate to $\mathrm{CO}_{2}$ and water. Strong ketogenesis from glycerol. Pronounced acid formation from D-glucose and $\mathrm{D}$-xylose as the $\mathrm{pH}$ of the medium drops below 4.5. No acid from or growth on lactose or starch. Produces 2-ketogluconic acid from Dglucose. No nitrate reduction, gelatin liquefaction, indol, or $\mathrm{H}_{2} \mathrm{~S}$ formation. Optimum temperature, 25 to $30^{\circ} \mathrm{C}$. No growth at $37^{\circ} \mathrm{C}$.

The occurrence of the phenons $A$ and $B$ raised the question of either (i) splitting the genus Gluconobacter into two species or (ii) subdividing Gluconobacter oxydans into two subspecies. There are several arguments against splitting. (i) Phenons A and B are differentiated by nicotinic acid requirement only. (ii) A high phenotypic clustering level of at least $\mathrm{S}_{\mathrm{SM}}=73 \%$ exists between the 98 Gluconobacter strains. (iii) Strains belonging to the four subspecies according to Bergey's Manual (21) are distributed randomly over both phenotypic and electrophoretic groups $\mathrm{A}\left(\mathrm{A}^{\prime}\right)$ and $\mathrm{B}\left(\mathrm{B}^{\prime}\right)$ (Table 1), and the type strains of the subspecies all cluster in phenon $B$ (Table 1), indicating that the subspecies listed in Bergey's Manual of Determinative Bacteriology (21) are not good biological groups. We also examined the position of old pre-1980 species names of Gluconobacter, such as "G. suboxydans," "G. roseus," "G. dioxyacetonicus," "G. cerinus," G. albidus," and a few others in our dendrograms. Strains of each of these species were distributed over both phenons A and B and frequently over several subgroups; they never clustered all together. These old species names do not represent real biological groups and are indeed best forgotten. (iv) The only strain available (IFO $12467^{\mathrm{T}}$ ) of $G$. oxydans subsp. sphaericus occupied a slightly separate position in cluster B' (Fig. 2) but not in phenon B (Fig. 1); the position of this strain does not justify separate subspecies status.

We, therefore, advocate a third alternativethat G. oxydans (Henneberg 1897) De Ley 1961, 47 remains the only species of the genus Glu- 
conobacter without further subdivision into subspecies. Phenons A and B are considered here as nicotinic acid-nonrequiring and -requiring biovars, respectively. This opinion is that to be expressed in the next edition of Bergey's Manual of Determinative Bacteriology. Strain ATCC $19357^{\mathrm{T}}$ (= NCIB $9013^{\mathrm{T}}$ ) remains the type strain. For phenon A, the phenotypic centrotype strain was calculated to be ATCC 15178, and for phenon B, strain NCIB 3734. These calculations were done by the method of Rogers and Tanimoto (43).

Colony variants, twin cultures, and descendant strains. Stable colony variants differing in color, form, and size were examined separately in the following 10 Gluconobacter strains: IFO 3251, IFO 3258, IFO 3262, IFO 3267, IFO 3268, IFO 3269, IFO 3285, LMD 29.7, LMD 37.1, and LMD 53.11. Colony variants differed not only in colony characteristics and growth rates but also in some other features. Pairs of colony variants showed from 89 to $95 \% \mathrm{~S}_{\mathrm{SM}}$. For eight strains, the colony variants of the same strain clustered together in the phenotypic and electrophoretic analyses.

We compared electropherograms of twin cultures of several Gluconobacter strains from the same original culture which had been maintained by different preservation methods in different culture collections, in some cases for over 40 years. Some cultures of the Institute for Fermentation, Osaka, Japan (IFO) and Laboratorium voor Mikrobiologie, Delft, Netherlands (LMD) had been maintained by serial transfers for years before they were lyophilized. Yet, protein electropherograms of twin cultures of several Gluconobacter strains were invariably found to be very similar or identical. For example, (i) the original strain of "Acetobacter suboxydans" isolated by Kluyver and de Leeuw (36) was maintained at the LMD as strain $23.2^{\mathrm{T}}$ since 1923, at the National Collection of Type Cultures, London, England (NCTC) since 1944, at the National Collection of Industrial Bacteria, Aberdeen, Scotland (NCIB) as NCIB 7069 since 1949 , and in the same collection as NCIB $621^{\mathrm{T}}$ since 1950; in addition there are a number of descendants such as NCIB 8035, NCIB 8036 (= ATCC $621 \mathrm{H}$ ), and NCIB 9498 (Fig. 3). (ii) Strain LMD 29.6 was isolated by J. Frateur in 1929 and maintained since then at LMD and as NCIB 8624 since 1954. (iii) Strain IFO 3262 was isolated by K. Kondô in 1941 and maintained at IFO since 1954 and as LMD 75.3 since 1975. The protein electropherograms of cultures of Gluconobacter maintained in our laboratory on GYC medium for 2 years by monthly transfer and their corresponding lyophilized cultures were always identical. Phenotypic testing of the duplicates and descendants of NCIB $621^{\mathrm{T}}$
(NCIB 7069, IFO $12528^{\mathrm{T}}$, NCIB 8035, and NCIB 9498) revealed an average $S_{S M}$ of $93 \%$, whereas their protein patterns showed an average $r$ of 0.95 .

The results obtained by both methods clearly prove the stability of these strains over several decades.

Natural habitats of Gluconobacter. The occurrence of Gluconobacter in grapes, wine, palm wine, cider, beer, vinegar, fruits, flowers, and bee hives and its role as a causal agent of pink disease of pineapple fruit has been discussed elsewhere (51). Gluconobacter has also been isolated from South African sour porridge, baker's yeast, fermenting Agave juice, and soft drinks (Table 1). Gluconobacter strains might play a role in postharvest losses of fruit by causing rot and browning $(57,58)$. They have been isolated repeatedly from rotting apples and pears. When injected into the apple varieties Jonared, Golden Delicious, Cox's Orange, and Belle de Boskoop, the isolates induced a necrotic reaction, with the apples showing rot and browning. The apple tissue degraded without soft rot. This phenomenon was accompanied by several shades of browning. Strains were reisolated and proven to be identical to the injected ones by polyacrylamide gel electrophoresis of soluble cell proteins. All Gluconobacter strains examined in the present study possessed the capacity to induce rot of apples and pears (58). Gluconobacter has been isolated frequently from soft drinks and lemonades $(16,45,46)$ and also from bees $(38,44)$. Lambert et al. (38) showed that two electrophoretically homogeneous groups of strains could be distinguished among isolates from bees in Belgium. One representative strain of each group was included in the present phenotypic study (LMG 79.37 and 79.87). The latter strain is a member of phenon $A$ and the electrophoretic subcluster $A^{\prime} 2$ (Fig. 3). Strain LMG 79.37, on the other hand, grouped in phenon $B$ and occupied a separate position in the electrophoretic cluster $B^{\prime}$ (Fig. 2). Most of the $A^{\prime} 1$ strains were isolated from fruit in Japan, a few from fruit in Belgium, and a few from soft drinks in the Netherlands.

It is also interesting to note that Gluconobacter strains isolated in 1941 from flowers in Japan (e.g., IFO 3276), strains isolated in the 1950s from beer in the Netherlands (NCIB 9108 and LMD 53.11), and strains isolated in 1979 from bees in Belgium (e.g., LMG 79.87) belong to the same subcluster $A^{\prime} 2$ and display almost identical protein electropherograms (Fig. 3), indicating that these strains from very different ecological and geographical niches are genetically highly related.

The strains of subcluster $A^{\prime} 3$ are of various origins. 
Most strains from the electrophoretic subcluster A' 4 have been isolated from fruits and flowers in Japan, and two were isolated from rotting pears in Belgium.

Most of the subcluster $B^{\prime} 1$ and $B^{\prime} 2$ strains are from beer, and some are from various sources such as fruits in Japan, sour porridge, etc. On the whole, one can say that B strains are mainly beer isolates and that A strains are mainly fruit isolates.

Acetobacter and Frateuria. Both Acetobacter and Frateuria are phenotypically and electrophoretically quite different from Gluconobacter (Fig. 1) (52). Both Acetobacter aceti subsp. liquefaciens strains examined, IFO $12388^{\mathrm{T}}(=$ IAM $1834^{\mathrm{T}}$ ) and NCIB 9417 , occupy a special position in Acetobacter closest to Gluconobacter (Fig. 1). In the past, these strains have been named Gluconobacter liquefaciens $(2,3,5$, $6,18)$. DNA:rRNA hybridizations (24) showed that strain NCIB 9417 is a member of the genus Acetobacter. This is further confirmed by its capacity to oxidize acetate and lactate to $\mathrm{CO}_{2}$ and water. The characteristics of these strains will be discussed in a forthcoming paper on the genus Acetobacter (F. Gosselé et al., manuscript in preparation).

\section{ACKNOWLEDGMENTS}

J.D.L. is indebted to the Fonds voor Kollektief Fundamenteel Onderzoek for research and personnel grants, J.S. and K.K. to the Nationaal Fonds voor Wetenschappelijk Onderzoek for research grants, and F.G. to the Instituut tot Aanmoediging van het Wetenschappelijk Onderzoek in Nijverheid en Landbouw for a scholarship.

We thank I. Banno (IFO), J. van der Toorn (LMD), and G. Kolfschoten for kindly supplying strains and valuable information.

\section{LITERATURE CITED}

1. Ameyama, M. 1975. Gluconobacter oxydans subsp. sphaericus, new subspecies isolated from grapes. Int. J. Syst. Bacteriol. 25:365-370.

2. Ameyama, M., and K. Kondô. 1966. Carbohydrate metabolism by the acetic acid bacteria. Part $V$. On the vitamin requirements for the growth. Agric. Biol. Chem. 30:203211.

3. Asai, T. 1935. Taxonomic studies on acetic acid bacteria and allied oxidative bacteria isolated from fruits. A new classification of the oxidative bacteria. J. Agric. Chem. Soc. Jpn. 11:499-513, 610-620, 674-708.

4. Asai, T. 1968. Acetic acid bacteria. Classification and biochemical activities. University of Tokyo Press, Tokyo.

5. Asai, T., H. Iizuka, and K. Komagata. 1964. The flagellation and taxonomy of the genera Gluconobacter and Acetobacter with reference to the existence of intermediate strains. J. Gen. Appl. Microbiol. 10:95-126.

6. Asai, T., and K. Shoda. 1958. The taxonomy of Acetobacter and allied oxidative bacteria. J. Gen. Appl. Microbiol. 4:289-311.

7. Aschner, M. 1937. Cultivation of cellulose-splitting bacteria on membranes of Acetobacter xylinum. J. Bacteriol. 33:249-252.

8. Barritt, M. M. 1936. The intensification of Voges-Proskauer reaction by the addition of $\alpha$-naphthol. J. Pathol. Bacteriol. 42:441-454.

9. Bauer, A. W., W. M. M. Kirby, J. C. Sherris, and M. Turck. 1966. Antibiotic susceptibility testing by a stan- dardized single disk method. Am. J. Clin. Pathol. 45:493497.

10. Bertrand, G. 1896. Préparation biochimique du sorbose. Bull. Soc. Chim. Fr. 15:627-631.

11. Bonham-Carter, G. F. 1967. Fortran IV program for Qmode cluster analysis of nonquantitative data using IBM $7090 / 7094$ computers. Kansas Geological Survey Computer Program. The University of Kansas, Lawrence.

12. Carr, J. G. 1958. Acetobacter estunense nov. spec. An addition to Frateur's ten basic species. Antonie van Leeuwenhoek J. Microbiol. 24:157-160.

13. Carr, J. G. 1968. Methods for identifying acetic acid bacteria. In B. M. Gibbs and D. A. Shapton (ed.), Identification methods for microbiologists, part B. Academic Press, Inc., London.

14. Cole, M. 1959. Bacterial rotting of apple fruit. Ann. Appl. Biol. 47:601-611.

15. Cooksey, K. E., and C. Rainbow. 1962. Metabolic patterns in acetic acid bacteria. J. Gen. Microbiol. 27:135-142.

16. Dachs, E. 1975. Gram-negative Bakterien im Erfrischungsgetränkebetrieb. Brauwelt 115:238-240.

17. De Felice, M., M. Levinthal, M. Iaccarino, and J. Guardiola. 1979. Growth inhibition as a consequence of antagonism between related amino acids: effect of valine in Escherichia coli K12. Microbiol. Rev. 43:42-58.

18. De Ley, J. 1961. Comparative carbohydrate metabolism and a proposal for a phylogenetic relationship of the acetic acid bacteria. J. Gen. Microbiol. 24:31-50.

19. De Ley, J. 1978. Modern molecular methods in bacterial taxonomy: evaluation, application, prospects. Proceedings of the 4th International Conference on Plant Pathology and Bacteriology. Angers, France.

20. De Ley, J., and J. Frateur. 1970. The status of the generic name Gluconobacter. Int. J. Syst. Bacteriol. 20:83-95.

21. De Ley, J., and J. Frateur, 1974. Genus Acetobacter Beijerinck 1898, 215, p. 276-278. In R. E. Buchanan and N. E. Gibbons (ed.), Bergey's Manual of Determinative Bacteriology, 8th ed. The Williams \& Wilkins Co., Baltimore.

22. Dhanvantari, B. N., D. W. Dye, and J. M. Young. 1978. Pseudomonas pomi Cole 1959 is a later subjective synonym of Acetobacter pasteurianus (Hansen 1879) Beijerinck 1898 and Pseudomonas melophthora Allen and Riker 1932 is a nomen dubium. Int. J. Syst. Bacteriol. 28:532537.

23. Frateur, J. 1950. Essai sur la systématique des Acétobacters. Cellule 53:287-392.

24. Gillis, M., and J. De Ley. 1980. Intra- and intergeneric similarities of the ribosomal ribonucleic acid cistrons of Acetobacter and Gluconobacter. Int. J. Syst. Bacteriol. 30:7-27.

25. Gonçalves de Lima, O., J. O. Falcão de Morais, and C. L. Carmona. 1955. Nova espécie de genero Acetobacter: $A$. lermae. An. Soc. Biol. Pernambuco 13:13-17.

26. Gosselé, F., J. Swings, and J. De Ley. 1980. Growth factor requirements of Gluconobacter. Zentralbl. Bakteriol. Parasitenkd. Infektionskr. Hyg. Abt. 1 Orig. Reihe C 1:348350 .

27. Gosselé, F., M. Van den Mooter, L. Verdonck, J. Swings, and J. De Ley. 1981. The nitrogen requirements of Gluconobacter, Acetobacter and Frateuria. Antonie van Leeuwenhoek J. Microbiol. 47:289-296.

28. Greenfield, S., and G. W. Claus. 1969. Isocitrate dehydrogenase and glutamate synthesis in Acetobacter suboxydans. J. Bacteriol. 100:1264-1270.

29. Hauge, J. G., T. E. King, and V. H. Cheldelin. 1955. Oxidation of dihydroxyacetone via the pentose cycle in Acetobacter suboxydans, J. Biol. Chem. 214:11-26.

30. Henneberg, W. 1897. Beiträge zur Kenntnis der Essigbakteriën. Zentralbl. Bakteriol. Parasitenkd. Infektionskr. Hyg. Abt. 2 3:223-231.

31. Kersters, K., and J. De Ley. 1975. Identification and grouping of bacteria by numerical analysis of their electrophoretic protein patterns. J. Gen. Microbiol. 87:333-342.

32. Kersters, K., and J. De Ley. 1980. Classification and 
identification of bacteria by electrophoresis of their proteins, p. 273-293. In M. Goodfellow and R. G. Board (ed.), Microbiological classification and identification. Society for Applied Bacteriology, Symposium Series no. 8. Academic Press, Inc., London.

33. Kerwar, S. S., V. H. Cheldelin, and L. W. Parks. 1964. Valine-leucine metabolism in Acetobacter suboxydans and the inhibition of growth by valine. J. Bacteriol. 88:179-186.

34. Kitos, P. A., T. E. King, and V. H. Cheldelin. 1955. Acetate activation in Acetobacter suboxydans. Fed. Proc. 14:236-237.

35. Kitos, P. A., C. H. Wang, B. A. Mohler, T. E. King, and V. H. Cheldelin. 1958. Glucose and gluconate dissimilation in Acetobacter suboxydans. J. Biol. Chem. 233:12951298.

36. Kluyver, A. J., and F. J. G. de Leeuw. 1924. Acetobacter suboxydans, een merkwaardige azijnzuurbakterie. Tijdschr. Vgl. Geneeskd. 10:170-182.

37. Kondô, K., and M. Ameyama. 1958. Carbohydrate metabolism by Acetobacter species. Part I. Oxidative activity for various carbohydrates. Bull. Agric. Chem. Soc. Jpn. 22:369-372.

38. Lambert, B., K. Kersters, F. Gosselé, J. Swings, and J. De Ley. 1981. Gluconobacters from honey bees. Antonie van Leeuwenhoek J. Microbiol. 47:147-157.

39. Leifson, E. 1954. The flagellation and taxonomy of species of Acetobacter. Antonie van Leeuwenhoek J. Microbiol. 20:102-110.

40. Loitianskaya, M. S., G. V. Pavlenko, and A. I. Ivchenko. 1979. Studies on the taxonomy of acetic acid bacteria. Mikrobiologiya 48:545-551.

41. Loitianskaya, M. S., G. V. Pavlenko, and G. A. Zolatareva. 1977. Type of flagellation in Acetobacter and Gluconobacter. Vestn. Leningr. Gos. Univ. 3:99-105.

42. Rhodes, M. E. 1958. The cytology of Pseudomonas spp. as revealed by a silver-plating staining method. J. Gen. Microbiol. 18:639-648.

43. Rogers, D. J., and T. T. Tanimoto. 1960 . A computer program for classifying plants. Science 132:1115-1118.

44. Ruiz-Argüeso, T., and A. Rodriguez-Navarro. 1975. Microbiology of ripening honey. Appl. Microbiol. 30:893896.

45. Sand, F. E. M. J. 1971. Zur Hygiene von Abfüllkolonnen der Erfrischungsgetränke-Industrie. Brauwelt 111:17881800.

46. Sand, F. E. M. J. 1976. Zum gegenwärtigen Stand der Getränkemikrobiologie. Brauwelt 116:220-230.

47. Shimwell, J. L. 1936. Study of a new species of Acetobacter (A. capsulatum) producing ropiness in beer and beerwort. J. Inst. Brew. 32:585-595.

48. Skerman, V. B. D., V. McGowan, and P. H. A. Sneath. 1980. Approved Lists of Bacterial Names. Int. J. Syst. Bacteriol. 30:225-420.

49. Sneath, P. H. A., and R. R. Sokal. 1973. The principles and practice of numerical classification. Freeman, San Francisco.
50. Stouthamer, A. H. 1959. Oxidative possibilities in the catalase positive Acetobacter species. Antonie van Leeuwenhoek J. Microbiol. 25:241-264.

51. Swings, J., and J. De Ley. 1981. The genera Gluconobacter and Acetobacter, p. 771-778. In M. P. Starr, H. Stolp, H. G. Trüper, A. Balows, and H. G. Schlegel (ed.), The prokaryotes. A handbook on habitats, isolation and identification of bacteria. Springer-Verlag, Berlin.

52. Swings, J., M. Gillis, K. Kersters, P. De Vos, F. Gosselé, and J. De Ley. 1980. Frateuria: a new genus for Acetobacter aurantius. Int. J. Syst. Bacteriol. 30:547-556.

53. Swings, J., K. Kersters, and J. De Ley. 1976. Numerical analysis of electrophoretic protein patterns of Zymomonas strains. J. Gen. Microbiol. 93:266-271.

54. Takahashi, T. 1907. Studies on diseases of saké. Bull. Coll. Agric. Tokyo Imp. Univ. 7:531-563.

55. Takahashi, T., and T. Asai. 1931. On gluconic acid fermentation. Part I. On Bacterium hoshigaki var. rosea nov. spec. Zentralbl. Bakteriol. Parasitenkd. Infektionskr. Hyg. Abt. 2 82:390-405.

56. Takahashi, T., and T. Asai. 1933. On gluconic acid fermentation. Part III. Zentralbl. Bakteriol. Parasitenkd. Infektionskr. Hyg. Abt. 2 87:385-412.

57. Vanden Abeele, P., C. Van Keer, J. Swings, F. Gosselé, and J. De Ley. 1980. Browning and rotting of apples caused by acetic acid bacteria. Meded. Fac. Landbouwwet. Rijksuniv. Gent. 45:391-397.

58. Van Keer, C., P. Vanden Abeele, J. Swings, F. Gosselé, and J. De Ley. 1981. Acetic acid bacteria as causal agents of browning and rot of apples and pears. Zentralbl. Bakteriol. Parasitenkd. Hyg. Abt. 1 Orig. Reihe C 2:197204.

59. Vaughn, R. H. 1942. The acetic acid bacteria. Wallerstein Lab. Commun. 5:5-26.

60. Vaughn, R. H. 1948. Acetobacter Beijerinck, p. 179-189. In R. S. Breed, E. G. D. Murray, and A. P. Hitchens (ed.), Bergey's manual of determinative bacteriology, 6th ed.

61. Vaughn, R. H. 1957. Acetobacter Beijerinck, p. 183-189. In R. S. Breed, E. G. D. Murray, and N. R. Smith (ed.), Bergey's manual of determinative bacteriology, 7 th ed. The Williams \& Wilkins Co., Baltimore.

62. Walker, T. K., and J. Tosic. 1945. Acetobacter infection. Part II. Studies of Acetobacter viscosum and Acetobacter aceti isolated, respectively, from top-fermentation beer and yeast. J. Inst. Brew. 51:245-250.

63. Williams, P. J. le B., and C. Rainbow. 1964. Enzymes of the tricarboxylic acid cycle in acetic acid bacteria. J. Gen. Microbiol. 35:237-247.

64. Wishart, D. 1978. Clustan user manual, 3rd ed. Program Library Unit, Edinburgh University, Edinburgh

65. Yamada, Y., Y. Okada, and K. Kondô. 1976. Isolation and characterization of "polarly flagellated intermediate strains" in acetic acid bacteria. J. Gen. Appl. Microbiol. 22:237-245. 